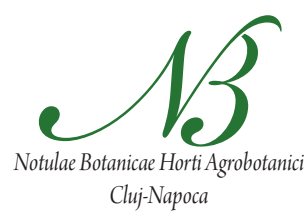

\title{
Evaluation of Triticale Genotypes in Terms of Yield Stability for the Southern Marmara Region
}

\author{
Ramazan DOGAN*, Oya KACAR, Erdinc GOKSU, Nedime AZKAN \\ Uludag University, Faculty of Agriculture, Bursa, Turkey; rdogan@uludag.edu.tr (*corresponding author)
}

\begin{abstract}
This research was conducted in three different locations of, Turkey, during the 2005-2006 and 2006-2007 growing seasons. In this study, eight triticale genotypes were used as trial material. The triticale genotypes 'C9', 'C11', 'Nx2015(17)' and 'Nx2003(12)', based on high grain yield and high stability, were identified as promising genotypes for the region. In particular, genotypes 'C9' and 'Nx2003(12)'

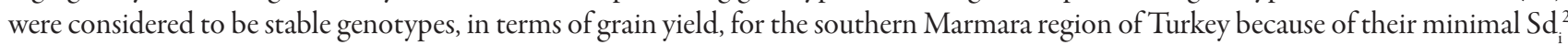
and $b_{i}$ values near 1 . In addition, genotype ' $N x 2003(12)$ ' had a higher grain yield than the general mean. Accordingly, this genotype is recommended as having especially good adaptability in all environments.
\end{abstract}

Keywords: triticale genotypes, genetic diversity, genotype x environment interaction, grain yield, stability

\section{Introduction}

Hexaploid triticale ( $x$ Triticosecale Wittmack) is a synthetic species. Previous studies have indicated that the grain production of newer and improved triticale cultivars, both as a monocrop and in small grain mixtures, is acceptable in a wide range of environments (Barnett et al., 2006; Juskiw et al., 2000 a, b; Pfeiffer, 1996). The forage production and silage yield as well as the quality of hexaploid triticales, both as a monocrop and in small grain mixtures, have been reported to be favorable in comparison with other small grains (Erekul and Kohn, 2006; Juskiw et al., 2000 a, b; Sun et al., 1996; Rao et al., 2000). These studies have indicated that triticale has great potential to fit into current small-grain areas and to contribute to the improvement of grain and forage production in diverse geographical environments. Triticale is, in general, more tolerant to environmental stresses than are wheat and barley (Jessop, 1996). Additionally, triticale combines high plant productivity and grain yield (Royo et al., 1999), good flavor after backing (Gupta and Priyadarshan, 1982) and stability to environmental variations (Hoerlein and Valentine, 1995). The increased acceptance and production of triticale will depend on obtaining information on the extent of genetic diversity available and on the response of triticale genotypes to a wide range of environmental conditions. It is widely accepted that information regarding germplasm diversity and genetic relatedness among elite breeding material is a fundamental element in plant breeding (Mukhtar et al., 2002; Siddiqui, 1994). Hence, the breeding of genotypes having a diverse genetic base is essential to achieve a desirable level of self-sufficiency and sustainability. According to Ashraf et al. (2001) the adaptability of a variety over diverse environments is usually indicated by the degree of its interaction with the different environments in which it is grown. A variety or genotype is considered to be more adaptive or stable if it has a high mean yield but a low degree of fluctuation in its yield when grown over diverse environments (Ashraf et al., 2001).

Regression coefficient is the nearest stability parameters (Eberhart and Russell, 1966; Finlay and Wilkinson, 1963). Severel methods have been proposed to analyze genotype environment interaction and phenotypic stability (Becker et al., 1988; Lin et al., 1986; Piepho, 1998). The genotype environment interaction from analysis of variance is portioned into heterogeneity of regression coefficients $\left(b_{i}\right)$ and the sum of deviations from regressions. Finlay and Wilkinson (1963) defined a genotype with regression coefficient equal to zero $\left(b_{i}=0\right)$ to be stable. According to joint regression model, a stable genotype is one with a high mean yield $\mathrm{b}_{\mathrm{i}}=1$ and $\mathrm{Sd}_{\mathrm{i}}{ }^{2}=0$ (Eberhart and Russell, 1966). Some stability studies have been carried out on different cereals in Turkey: Akcura et al. (2004), Aktas et al. (2009), Akgun et al. (2011) in triticale, Kara et al. (2000), Bayram et al. (2009), Dogan et al. (2009) in wheat and Akcura et al. (2005) in oat.

The purpose of this research was to determine genotype $\mathrm{x}$ environment interaction and phenotypic stability of the triticale lines over three environments.

\section{Materials and methods}

In this study, four triticale genotypes developed by the crossing method in the Agriculture Faculty of Uludag University (Coplu et al., 2001) and three lines obtained from CIMMYT were studied in terms of yield in the southern Marmara region of Turkey. Variety 'Nörtingen' was used as the standard cultivar (Tab. 1).

Eight diverse winter triticale genotypes were examined in a randomized-blocks design with three replications in the years 2005-2006 and 2006-2007. Grain yield of genotypes was measured in all three environments (Bursa, $40^{\circ}$ 
Tab. 1. The new genotypes and standard cultivar used in the study

\begin{tabular}{crc}
\hline Genotypes and standard cultivars & Pedigree & Source \\
\hline 'C6 & GIRAF/YOGUI-1FARAS-1/3LAMB-4(CTM88. 1948 -3RES-1M-0Y-2M-3Y-0M) & CIMMYT \\
'C9' & LAMB-2(X65985-5M-3Y-2M-1Y-4M-1Y-1M-0Y) & CIMMYT \\
'C11' & CAGUAN-3 (CTM86M-2281-5Y-2B-1Y-1B-2RES-0B-1Y-OPAP) & CIMMYT \\
'Nörtingen x 2015(17)' & New Line \\
'Nörtingen x 2003(12)' & 2003 (Juannillo 98x21295-OAP) & New Line \\
'Nörtingen x Eronga(3)' & New Line \\
'Nörtingen x Eronga(14)' & New Line \\
'Nörtingen (Standard)' & Germany \\
\hline
\end{tabular}

Tab. 2. Precipitation in 2005-2006, 2006-2007 and long-term (1975-2007) in Bursa, Eskisehir and Sakarya

\begin{tabular}{|c|c|c|c|c|c|c|c|c|c|}
\hline \multirow{3}{*}{$\begin{array}{l}\text { The } \\
\text { months of } \\
\text { the year }\end{array}$} & \multicolumn{9}{|c|}{ Precipitation $(\mathrm{mm})$} \\
\hline & \multicolumn{3}{|c|}{ Bursa } & \multicolumn{3}{|c|}{ Eskisehir } & \multicolumn{3}{|c|}{ Sakarya } \\
\hline & $2005-2006$ & $2006-2007$ & Long-term & $2005-2006$ & $2006-2007$ & Long-term & $2005-2006$ & $2006-2007$ & Long-term \\
\hline October & 33.0 & 25.8 & 38.6 & 11.5 & 47.5 & 29.2 & 91.8 & 50.3 & 88.2 \\
\hline November & 109.3 & 101.1 & 68.4 & 48.0 & 16.8 & 34.9 & 165.7 & 64.6 & 87.7 \\
\hline December & 87.7 & 27.9 & 96.5 & 17.0 & 6.8 & 43.3 & 76.6 & 74.4 & 103.2 \\
\hline January & 59.9 & 86.8 & 81.1 & 45.3 & 42.2 & 40.0 & 77.5 & 100.8 & 93.7 \\
\hline February & 132.5 & 21.1 & 66.9 & 34.5 & 14.2 & 27.5 & 98.6 & 17.9 & 72.3 \\
\hline March & 57.0 & 57.9 & 61.0 & 23.9 & 24.0 & 31.4 & 67.2 & 55.8 & 67.8 \\
\hline April & 13.0 & 32.8 & 66.0 & 2.9 & 25.0 & 43.9 & 3.3 & 50.5 & 61.6 \\
\hline May & 9.3 & 12.1 & 44.1 & 20.7 & 65.6 & 46.8 & 13.8 & 53.9 & 48.2 \\
\hline June & 62.8 & 47.2 & 33.8 & 13.6 & 58.6 & 25.7 & 101.0 & 29.6 & 69.5 \\
\hline Total & 564.5 & 413.1 & 556.4 & 217.4 & 300.7 & 322.7 & 695.5 & 497.8 & 692.2 \\
\hline
\end{tabular}

$\mathrm{W}$ and $28^{\circ} 30^{\prime} \mathrm{N}$, Eskisehir $29^{\circ} 32^{\prime} \mathrm{E}$ and $39^{\circ} 40^{\prime} \mathrm{N}$, Sakarya $30^{\circ} \mathrm{E}$ and $\left.40^{\circ} \mathrm{N}\right)$.

Precipitation patterns and amount differed markedly between the 2005-06 and 2006-07 growing seasons for all provinces (Anonymous, 2008). The distribution of precipitation is uneven and nearly $90 \%$ occurs during the period when wheat exists in the field for almost all province (Tab. 2).

The plots were 8 rows, $10 \mathrm{~m}$ in length with $15 \mathrm{~cm}$ between rows, with the harvested area $=12 \mathrm{~m}^{2}$.

\section{Statistical analyses}

Analyses of variance were computed for the seed yield data within and across the six years of the study. The variance of "Homogenity of Regressions" and "RegressionBiased Variance" were partitioned from the cultivar $\mathrm{x}$ year interaction sum of squares in the analyses of variance (Eberhart and Russell, 1966; Yildirim et al., 1979). The "Simple Regression Method" was used in estimating the adaptation and stability parameters (Finlay and Wilkinson, 1963). The regression coefficient $\left(b_{i}\right)$, regression-biased square means $\left(S^{2}, \mathrm{xi}\right)$.

1. Regression coefficient $\left(b_{i}\right)$ for 1 th genotype proposed by Finlay and Wilkinson (1963) was defined by the following formula:

$$
b i=\frac{\sum_{j=1}^{m} Y_{i j X i j}-\frac{(Y i)(X)}{m}}{\sum_{j=1}^{m} x j^{2}-\frac{X^{2}}{m}}
$$

where $\mathrm{i}$ and $\mathrm{j}$ explain genotype (1-8) and environment (1-6), respectively. In addition, $\mathrm{m}$ was number of environments.

2. Mean squares of deviations from regression $\left(\mathrm{Sd}_{\mathrm{i}}{ }^{2}\right)$ proposed by Eberhart and Russell (1966) was calculated by the following equation:

$$
\mathrm{Sdi}^{2}=\frac{1}{\mathrm{~m}-2}\left[\left(\sum_{\mathrm{j}=1}^{\mathrm{m}} \mathrm{Yij}^{2}-\frac{\mathrm{Yi}^{2}}{\mathrm{~m}}\right) \mathrm{bi}^{2}\left(\sum_{\mathrm{j}=1}^{\mathrm{m}} \mathrm{Xj}^{2}-\frac{\mathrm{X}^{2}}{\mathrm{~m}}\right)\right]
$$

were $\mathrm{bi}^{2}$ was square of regression coefficient for genotype,

and the term $\sum_{j=1}^{m} \mathrm{Yij}^{2}-\frac{\mathrm{Yi}^{2}}{\mathrm{~m}}$

was sum of squares of dependent variable (genotype).

All data were subjected to analysis of variance for each character using MSTAT-C (version 2.1 Michigan State University of Texas at Austin). The significant of genotype, year and cultivar $\mathrm{x}$ year (Environment) interactions were determined at 0.05 and 0.01 probability levels, by the F-test. The F protected least significant difference (LSD) was calculated at 0.05 probability level according to Steel and Torrie (1980).

\section{Results and discussion}

Each experimental year in the three locations was considered to represent an environment, and the mean of each environment was taken as an environmental index. 
Tab. 3. The mean squares of analysis of variance of triticale genotypes

\begin{tabular}{cccccccc}
\hline \multirow{2}{*}{ Source of variation } & \multirow{2}{*}{ DF } & \multicolumn{2}{c}{ Bursa } & \multicolumn{2}{c}{ Eskisehir } & \multicolumn{2}{c}{ Sakarya } \\
& & $2005-2006$ & $2006-2007$ & $2005-2006$ & $2006-2007$ & $2005-2006$ & $2006-2007$ \\
\hline Blocks & 2 & 9508.3 & 704.0 & $698.2^{*}$ & 11.7 & 95.0 & 310.2 \\
Genotypes & 7 & $9752.5^{* *}$ & 5009.0 & $6526.3^{* *}$ & $2.87^{*}$ & $13003.0^{* *}$ & $5632.6^{* *}$ \\
Experimental Error & 14 & 950.5 & 1883.0 & 666.0 & 251.0 & 621.0 & 455.1 \\
Total & 23 & & & & & \\
\hline
\end{tabular}

***: Significant at 0.05 and 0.01 probability levels, respectively

The results of analysis of variance for the grain yields of the triticale genotypes in six environments, including each experimental year in three locations, are shown in Tab. 3. Significant differences among grain yields of genotypes were found. Non significant differences were found only for Bursa during the 2005-2006 growing season.

The combined analyses of variance for the experiment on grain yields in six environments are given in Tab. 4 .

The differences in grain yield among environments (E), blocks (B), and genotypes (G) were statistically significant at the $1 \%$ level . In addition, Genotype $\mathrm{x}$ Environment interaction was significant at the $1 \%$ level of probability. Pham and Kang (1988) indicated that genotype x environment interactions minimize the usefulness of genotypes by confounding their yield performance. Becker and Leon (1988) also indicated that assessment of stability across many locations and years could increase both repeatability and heritability of important traits. There is significant effects of years in terms of genotype's yields. Not only means

Tab. 4. The combined analyses of variance for the sixenvironment study of grain yields of genotypes

\begin{tabular}{lccc}
\hline \multicolumn{1}{c}{ Source of variation } & D.F. & $\begin{array}{c}\text { Sum of } \\
\text { Squares }\end{array}$ & $\begin{array}{c}\text { Means of } \\
\text { Squares }\end{array}$ \\
\hline Blocks (B) & 12 & 19707.8 & $1642.3^{* *}$ \\
\hline Genotype (G) & 7 & 139505.0 & $19929.3^{* *}$ \\
Environment (E) & 5 & 2717860.6 & $543572.1^{* *}$ \\
Genotype x Environment (GxE) & 35 & 147290.0 & $4208.3^{* *}$ \\
$\quad$ Homogeneity of Regressions & 7 & 9334.8 & 1333.5 \\
$\quad$ Residual & 28 & 137955.3 & 4926.9 \\
Experimental Error & 84 & 70011.4 & 833.5 \\
\hline \multicolumn{1}{c}{ Total } & 143 & 3094374.8 & \\
\hline \multicolumn{3}{c}{} \\
\hline
\end{tabular}

of genotypes but also stability parameters must be considered on the evaluation of genotypes (Akgun et al., 2011; Ilker et al., 2009).

Genotype $\mathrm{x}$ Environment interaction was significant owing to the high significance of the residuals (mean square deviation from the regression). The significant $G x$ $\mathrm{E}$ interaction indicated that genotypes were not stable in terms of grain yield (Tab. 4).

The grain yield values of triticale genotypes for individual environments and the overall means for the six-environments are shown in Tab. 5. The stability parameters for all cultivars are given in Tab. 6. Eberhart and Russell (1996) emphasized the need of considering both linear $\left(b_{i}\right)$ and non-linear $\left(\mathrm{Sd}_{\mathrm{i}}^{2}\right)$ components of genotype-environment interactions in judging the stability of a genotype. A wide adaptability genotype was defined as one with $b_{i}=1$ and high stability as one with $S d_{i}{ }^{2}=0$. In this study values for the regression coefficient $\left(\mathrm{b}_{\mathrm{j}}\right)$ ranged from $0.824\left[{ }^{\mathrm{N}} \mathrm{NxE}\right.$ (14)'] to 1.180 ['Nx2015(17)'] for grain yield (Tab. 6).

Based on the average yield for the six environments, four of the eight triticale genotypes had higher yields than the average found in the trials. These higher yielding genotypes were 'C9', 'C11', 'Nx2015(17)' and 'Nx2003(12)' . The genotypes 'C9', 'C11', 'Nx2015(17)', Nx 23003(12), 'NxE(3)' and 'Nörtingen' (Std.) were in the same statistical group, whereas genotype ' $\mathrm{NxE}(14)$ ' formed a different group. This genotype (' $\mathrm{NxE}(14)$ ') had a lower yield value $\left(5549 \mathrm{~kg} \mathrm{ha}^{-1}\right)$ than the average yield value for the trial $\left(6027 \mathrm{~kg} \mathrm{ha}^{-1}\right)$.

Based on the average values over all environments, four genotypes ('C9', 'C11', 'Nx2015(17)' and 'Nx2003(12)'), with values of $b_{i}=1$ and $S d_{i}{ }^{2}=0$, were considered to be stable (Tab. 6).

Tab. 5. The seed yields of triticale genotypes in individual environments

\begin{tabular}{cccccccc}
\hline \multirow{2}{*}{ Genotypes } & \multicolumn{3}{c}{$(2005-2006)$} & & & \multirow{2}{*}{ Means } \\
\cline { 2 - 6 } & Bursa & Eskisehir & Sakarya & Bursa & Eskisehir & Sakarya & \\
\hline 'C6 & $7356 \mathrm{c}$ & $6479 \mathrm{c}$ & $7069 \mathrm{~cd}$ & 5501 & $3384 \mathrm{ab}$ & $5132 \mathrm{bc}$ & $5820 \mathrm{bcd}$ \\
'C9' & $7990 \mathrm{abc}$ & $7524 \mathrm{a}$ & $7248 \mathrm{bc}$ & 6168 & $3737 \mathrm{a}$ & $5368 \mathrm{ab}$ & $6339 \mathrm{abc}$ \\
'C11' & $8151 \mathrm{ab}$ & $6672 \mathrm{bc}$ & $8005 \mathrm{a}$ & 6201 & $3679 \mathrm{ab}$ & $5737 \mathrm{a}$ & $6402 \mathrm{ab}$ \\
'Nx2015(17)' & $8314 \mathrm{a}$ & $7498 \mathrm{a}$ & $6855 \mathrm{cde}$ & 5359 & $3483 \mathrm{ab}$ & $4744 \mathrm{~cd}$ & $6042 \mathrm{abcd}$ \\
\hline 'NxE(3)' & $7844 \mathrm{abc}$ & $7273 \mathrm{ab}$ & $7700 \mathrm{ab}$ & 6456 & $3674 \mathrm{ab}$ & $5581 \mathrm{ab}$ & $6421 \mathrm{a}$ \\
'NxE(14)' & $7502 \mathrm{bc}$ & $6707 \mathrm{bc}$ & $6439 \mathrm{ef}$ & 5520 & $3624 \mathrm{ab}$ & $4780 \mathrm{~cd}$ & $5762 \mathrm{~cd}$ \\
'Nörtingen' (Std.) & $6518 \mathrm{~d}$ & $6650 \mathrm{bc}$ & $6035 \mathrm{f}$ & 6222 & $3329 \mathrm{~b}$ & $4543 \mathrm{~d}$ & $5549 \mathrm{~d}$ \\
Means & $7888 \mathrm{abc}$ & $6344 \mathrm{c}$ & $6550 \mathrm{def}$ & 5952 & $3689 \mathrm{ab}$ & $4844 \mathrm{~cd}$ & $5878 \mathrm{abcd}$ \\
\hline
\end{tabular}


252

Tab. 6. Statistical indicators of the adaptation and stability of the triticale genotypes studied

\begin{tabular}{cccc}
\hline & \multicolumn{3}{c}{ Grain yield } \\
\hline Genotypes & $\overline{\mathrm{X}}$ & $\begin{array}{c}\mathrm{b}_{\text {i }} \text { (regression } \\
\text { coefficients) }\end{array}$ & $\begin{array}{c}\mathrm{S}^{2} \text { y.xi (regression } \\
\text { biased square means) }\end{array}$ \\
\hline 'C6 & $5820 \mathrm{bcd}$ & 0.969 & 580.8 \\
'C9' & $6339 \mathrm{abc}$ & 1.054 & 278.8 \\
'C11' & $6402 \mathrm{ab}$ & 1.060 & $2168.1^{* *}$ \\
'Nx2015(17)' & $6042 \mathrm{abcd}$ & 1.180 & $2158.3^{* *}$ \\
'Nx2003(12)' & $6421 \mathrm{a}$ & 1.046 & 634.6 \\
'NxE(3)' & $5762 \mathrm{~cd}$ & 0,920 & 330.9 \\
'NxE(14)' & $5549 \mathrm{~d}$ & 0,824 & $2729.3^{* *}$ \\
'Nörtingen' (Std.) & $5878 \mathrm{abcd}$ & 0,947 & $1059.7^{* *}$ \\
\hline Means & 6027 & & \\
\hline
\end{tabular}

$\overline{\mathrm{X}}$ : Mean grain yield $\left(\mathrm{kg} \mathrm{ha}^{-1}\right)$; $\mathrm{b}_{\mathrm{i}}$ : regression coefficient, $\mathrm{Sd}_{\mathrm{i}}^{2}$ : deviation from regression (Eberhart and Russell,1966). ${ }^{* * *}$ : Significant at 0.05 and 0.01 probability levels, respectively.
Marmara region of Turkey because of their minimal $\mathrm{Sd}_{i}{ }^{2}$ values and $b_{i}$ values near 1 . However, genotypes ' $\mathrm{C} 6$ ' and ' $\mathrm{NxE}(3)$ ' had lower grain yields than the general mean and $b_{i}$ values near 1 . These genotypes were considered to have poor adaptability to all environments.

Temperature and precipitation that varied across environments were major environmental factors affecting triticale yield (Akgun et al., 2011; Dogan et al., 2009; Frere et al.,1987; Korkut et al., 2001). As seen from Tab. 5, there were significant variations in grain yields. It is known that variation in yield were due to annual precipitation and also, variations of precipitation in critical months (especially; March, April and May). Stability analysis identified stable genotypes for grain yield. Some genotypes were considered to have high adaptability to good environments, and several other genotypes were considered to have high adaptability to unfavorable conditions. The genotypes 'C9', 'C11', 'Nx2003(12)' and 'Nx2015(17)' were determined to be

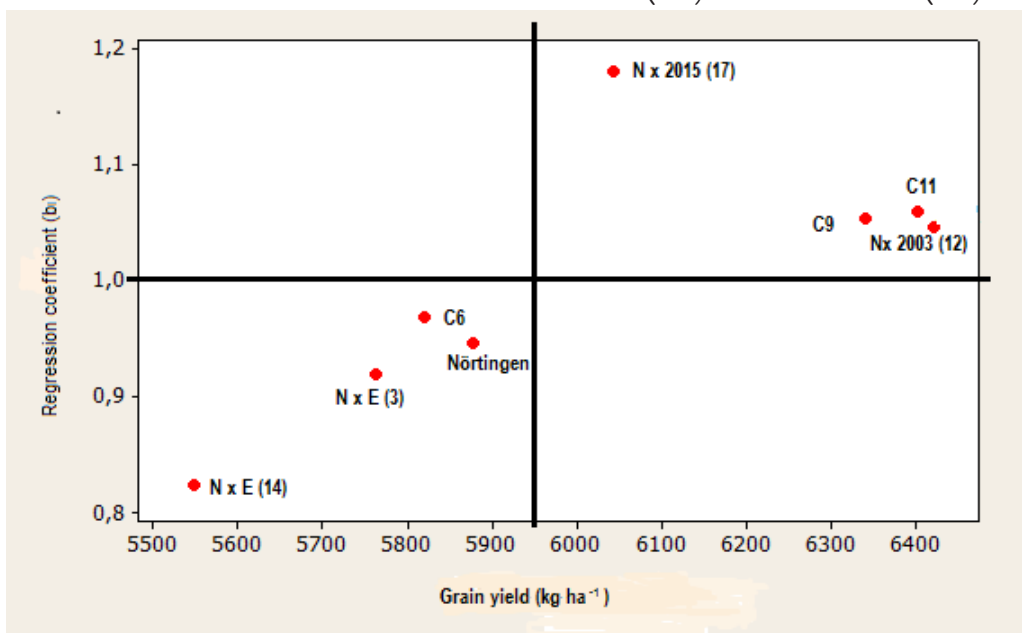

Fig. 1. Plot of deviation from regression coefficient against grain yield in a stability study of eight triticale genotypes

Several genotypes were found to have $b_{i}$ values near 1. However, the mean square deviations from the regression $\left(\mathrm{Sd}_{\mathrm{i}}{ }^{2}\right)$ were highly significant for the genotypes ' $\mathrm{C} 11$ ', 'Nx2015(17)', 'NxE(14)' and 'Nörtingen' (Std.). Therefore, results based on stability parameters and grain yield of genotypes indicated that genotypes ' $\mathrm{NxE}(14)$ ' and 'Nörtingen' had poor adaptability to unfavorable environmental conditions. These genotypes had lower grain yields than the general mean, and they had highly significant $S_{i}{ }^{2}$ values (Tab. 6). The genotypes 'C11' and 'Nx2015(17)' were considered to have good adaptability to favorable environmental conditions because they exhibited highly significant $S d_{i}^{2}$ values and higher grain yields than the general mean. The genotypes 'C11' and 'Nx2015(17)' had higher grain yields than the general mean and $b_{i}$ values near 1 . However, these genotypes were not considered to be stable, owing to their high $S d_{i}^{2}$ values. Triticale genotypes 'C9' and 'Nx2003(12)' had higher grain yields than the general mean and $b_{i}$ values near 1 . These genotypes were considered to have good adaptability to all environments. Genotypes 'C9' and 'Nx2003(12)' were considered to be stable genotypes in terms of grain yield for the southern the most suitable cultivars for the conditions of the region, based on the results of the trials (Fig. 1). These genotypes may be recommended for triticale production areas in the southern Marmara region, owing to their stability and good adaptability to all environments. However, genotypes 'C6', 'NxE(3)', 'NxE(14)' and cv. 'Nörtingen' (Std.) exhibited poor adaptability to unfavorable environmental conditions or to all environments.

\section{Conclusions}

This study evaluated the response to environmental conditions and the yield performance of several triticale genotypes. According to the results of the analysis of variance, significant differences between environments and genotypes and significant Genotype $x$ Environment interaction effects were found for grain yield.

The results of the present study indicate that considerable genetic diversity and environmental stability for yield are present in triticale and that genetic improvement programs should be successful in developing cultivars with high yield adapted to a broad range of environments. 


\section{References}

Akcura M, Ozer E, Taner S (2004). Stability analyses for grain yield of triticale genotypes. J Crop Res 1:36-43.

Akcura M, Ceri S, Taner S, Kaya Y, Ozer E, Ayranci R (2005). Grain yield stability of winter oat (Avena sativa L.) cultivars in the Central Anatolian region of Turkey. Central Eur Agricult 6(3):203-210.

Akgun I, Altindal D (2011). Stability analysis and grain yield in some triticale genotypes. SDU, J Fac Agricult 6(1):7-14.

Aktas B, Aydemir T, Yilmaz K, Ikincikarakaya S (2009). Stability analysis of grain yield of some triticale ( $x$ Triticosecale Witt.) in arid conditions. J Field Crops Cen Res Inst 18(1-2):3035.

Anonymous (2008). Precipitation values for Bursa, Eskisehir and Sakarya province. Turkish State Meteorological Service, Climatic Data, Ankara.

Ashraf M, Qureshi AG, Khan NA (2001). Genotypeenvironment interaction in wheat. Online J Bio Sci 1(5):356367.

Bayram ME, Demir L (2009). Yield stability of some bread wheat (Triticum aestivum L.) cultivars grown in Marmara Ecology. J Agricult Fac Uludag Univ 23(1):1-12.

Barnett RD, Blount AR, Pfahler PL, Bruckner PL, Wesenberg DM, Johnson JW (2006). Environmental stability and heritability estimates for grain yield and test weight in triticale. J Appl Genet 47(3):207-213.

Becker HB, Leon J (1988). Stability analysis in plant breeding. Plant Breed 101:1-23.

Coplu N (2001). Quantitative and cytological analysis at diallel crosses of some triticale genotypes (Phd Thesis), Uludag University, Agricultural Faculty, Bursa, Turkey.

Dogan R, Aycicek M (2009). Adaptability performances of some soft wheat (Triticum aest. var. aest. L.) cultivars in the Marmara Region of Turkey. Pak J Bot 41(3):1069-1076.

Eberhart SA, Russell WA (1966). Stability parameters for comparing varieties. Crop Sci 6:36-40.

Erekul O, Kohn W (2006). Effect of weather and soil conditions on yield components and bread-making quality of winter wheat (Triticum aestivum L.) and winter triticale (Triticosecale Wittm.) varieties in North-East Germany. J Agron Crops Sci 192:452-464.

Frere M, Maracchi G, Migliette F, Canes C (1987). Agroclimatogical classification of the Mediterranean and Southwest Asia areas, 3-13 p. In: Rivastava JP, Porceddu E, Acevedo E, Varma S (Eds.). Drought Tolerance in Winter Cereals. Proc. Intern. Workshop. 27-31 October, Italy.

Finlay KW, Wilkinson GN (1963). The analysis of adaptation in a plant breeding programme. Aust J Agric Res 14:742-754.

Gupta PK, Priyadarshan PM (1982). Triticale: present status and future prospects. Adv Genet 21:255-345.

Hoerlein AD, Valentine J (1995). Triticale (x Triticasecale), 186203 p. In: Williams LT (Ed.). Cereals and Pseudocereals. Chapman and Hall Press, London.
Ilker E, Altinbas M, Tosun M (2009). Selection for test weight and kernel weight in high yielding wheat using a safety-first index. Turk J Agric For 33(1):37-45.

Jessop RS (1996). Stress tolerance in newer triticales compared to other cereals, 419-427 p. Guedes-Pinto E, Darvey N, Canide V (Eds.). Triticalé. Today and Tomorrow. Kluwer Acad Publ, Dorecht, London.

Juskiw PE, Helm JH, Salmon DF (2000a). Competitive ability in mixtures of small grain cereals. Crop Sci 40:159-164.

Juskiw PE, Helm JH, Salmon DF (2000b). Forage yield and quality for monocrop and mixtures of small grain cereals. Crop Sci 40:138-147.

Kara SM, (2000). Adaptation and stability analysis in some bread wheat genotypes. Turk J Agric For 24:413-419.

Korkut KZ, Baser I, Bilgin O (2001). Evaluation of advanced bread wheat (T. aestivum L.) lines for grain yield and some yield components. Field Crops Congress, 17-21 p.

Lin CS, Binns MR, Lefkovitch LP (1986). Stability analysis: Where do we stand? Crop Sci 26:894-900.

Mukhtar MS, Rahman M, Zafar Y (2002). Assessment of genetic diversity among wheat (Triticum aestivum L.) cultivars from a range of localities across Pakistan using random amplified polymorphic DMA (RAPD) analysis. Euphytica 128:417425.

Pham HN, Kang MS (1988) Interrelationships among respectability of several stability statistics estimated from international maize trials. Crop Sci 28:925-928.

Pfeiffer WH (1996). Triticale: Potential and research status of a man-made cereal crop, 571-580 p. In: Guedes-Pinto H, Darvey N, Carnide VP (Eds.). Triticale: Today and Tomorrow. Dordrecht, Kluwer Acad Publ.

Piepho HP (1998). Empirical best linear unbiased prediction in cultivar trials using factor analytic variance covariance structures. Theor Appl Genet 97:195-201.

Rao SC, Coleman SW, Volesky JD (2000). Yield and quality of wheat, triticale, and Elytricum forage in the southern plains. Crop Sci 40:1308-1312.

Royo C, Voltas J, Romagosa I (1999). Remobilization of preanthesis assimilates to the grain for grain only and dual purpose (forage and grain) Triticale. Agron J 91:312-316.

Siddiqui KA (1994). New advances in plant breeding, 135-193 p. In: Bashir E, Bantel R (Eds.). Plant Breeding, National Book Foundation, Islamabad.

Steel RGD, Torrie JH (1980). Principles and procedures of statistics. A biometrical approach. $2^{\text {nd }}$ ed. Mc Graw-Hill, New York.

Sun YS, Vie Y, Wang ZY, Hai L, Chen XZ (1996). Triticale as forage in China, 879-886 p. In: Guedes-Pinto H, Darvey N, Carnide VP (Eds.). Triticale: Today and Tomorrow. Dordrecht, Kluwer Acad Publ.

Yildirim MB, Ozturk A, Ikiz EB, Puskullu H (1979). Statisticalgenetical methods in plant breeding. Agricultural Research Institute. Menemen-Izmir. 